Ambient Science, 2020: Vol. 07(Sp1); 33-38

DOI:10.21276/ambi.2020.07.sp1.oa04

\title{
Attitudes Towards Nutritional Sport Supplement of National and
} International Kickboxers

\section{Süleyman Ulupinar ${ }^{1}$, Serhat Özbay², Cebrail Gençoglu², Abdullah Bora Özkara²}

${ }^{1}$ Ministry of Education, Ermenek District National Education Directorate, Karaman, Turkey

${ }^{2}$ Erzurum Technical University, Sport Sciences Faculty, Erzurum, Turkey

Study Area: Erzurum, Turkey

Coordinates: $41^{\circ} \mathrm{oo}^{\prime} 49^{\prime \prime} \mathrm{N} 28^{\circ} 57^{\prime} 18^{\prime \prime} \mathrm{E}$

Key words: Ergogenic aids, Exercise, Combat sports

\section{Introduction:}

Kickboxing is a combat sport where kicks and punches can be used, taking its origin from Karate, Thai boxing and western boxing, (Gartland et al., 2001) and it is mostly used for self-defense. The popularity of kickboxing is rapidly growing and has approximately one million participants worldwide (Gartland et al., 2001; Zazryn et al., 2003). Kickboxing competitions are held under World Associations of Kickboxing Organizations International Federation (WAKO) rules, and athletes who do not comply with these rules are penalized or disqualified during the competition (Heil, 2010). Kickboxers are expected to have an high level of anaerobic capacity to maintain the highintensity power-requiring movements during a fight, also need aerobic capacity to resynthesize the high-energy phosphates consumed (Özbay \& Ulupinar, 2020; Slimani et al., 2017).

\section{Abstract}

This study aims to investigate the nutritional ergogenic aids attitudes levels of the active Turkish kickboxers in terms of gender, competition weight, competition category, education status, income levels, and the status of the kickboxers whether international athletes or not. The Attitude Scale toward Nutritional Sports Supplements (ATNSS) was used in this study, which consists of the subdimensions benefit, side effects and ethics, natural nutrition. The side effects, ethics and natural nutrition subdimensions of female athletes were significantly higher than male athletes. When the relationship between income level and ATNSS sub-dimensions was examined, the side effects and ethics sub-dimension was significantly lower in the athletes with low income than the athletes with middle and higher income. Examining ATNSS' sub-dimensions according to their university education levels, the benefit sub-dimensions scores of athletes studying at the faculty of sports sciences were significantly higher than the athletes who did not study in the sports departments. Further, the benefit sub-dimension scores of the international kickboxers were significantly higher, and the side effect and ethic and natural nutrition sub-dimension scores were significantly lower than the national kick boxers. Conclusively, it is thought that informing the kickboxers about nutritional ergogenic sports supplements may be important in terms of increasing awareness and sporting performance in this area.

Sufficient and balanced consumption of basic nutritional components is defined as appropriate nutrition for reasons such as supplying the energy needs of our body, protecting our health, maintaining physical growth and development, treating diseases and/or injuries, adapting to long-term training and increasing the effectiveness of training (Ersoy, 2010; McArdle et al., 2012; Zorba, 1999). Proper nutrition plays a crucial role in maximizing sporting performance, adaptation to high-intensity trainings, and recovery after the trainings. In short, optimal nutrition is accepted as one of the most important factors affecting success in sports (Rodriguez et al., 2009).

In recent years, the use of ergogenic aids has become widespread among athletes to increase performance. Especially in competition sports, the fact that medals are obtained with a split-second difference has pushed the athletes to search for a new methods besides trainings

*Corresponding Author:cebrail.gencoglu@erzurum.edu.tr 
(Ünal, 2005). The use of some substances other than natural skills and training in order to increase the performance of athletes is called ergogenic aid (Argan \& Hüseyin, 2009; Ünal, 2005). As a sports term, ergogenic aid is a method or practice that increases performance capacity, work efficiency, and allows easier recovery after exercises or adaptation to strenuous training (Kreider, 2003; Leutholtz \& Kreider, 2001). The effects of nutrition before, during and after exercise on sporting performance are inevitable and there is a lot of research on this subject (Hargreaves et al., 2004; Heaney et al., 2010; Himes, 1991; Holway \& Spriet, 2011; Jentjens \& Jeukendrup, 2003; Ormsbee et al., 2014; Ozan et al., 2020; Rico-Sanz, 1998; Stand, 1996; Tarnopolsky et al., 1988; Tawfik et al., 2016). Therefore, athletes turn to ergogenic aids to compensate for nutritional deficiencies during intense training periods and to maintain their performance maximally (Maughan, 1999).

Some of the ergogenic aids have been accepted as doping by the International Olympic Committee (IOC), the World Anti-Doping Agency (WADA) and the International Sports Federations since they directly threaten the health of the athletes or eliminates the conditions for equal competition among athletes (Argan \& Hüseyin, 2009; Ünal, 2005). For example; Ephedrine and pseudoephedrine may be ergogenic but havedeleterious cardiovascular effects (Juhn, 2003). Similarly, erythropoietin may be ergogenic yet it increases the risks of thromboembolic events (Singbartl, 1994; Sunder-Plassmann \& Hörl, 2001). Human growth hormone and insulin growth factor-I decrease body fat and may increase lean muscle mass when given subcutaneously but has many adverse effect for the human metabolism (Rudman et al., 1990; Sonksen, 2001). Anabolic steroids increase the protein synthesis and muscle mass of the body, but have many adverse effects, some of which are irreversible (Bahrke et al., 2000; Kutscher et al., 2002; Shahidi, 2001). Therefore, athletes should avoid substances on the WADA prohibited list for both to avoid negative effects of them and not to violate the conditions of equal competition and the spirit of fair-play.

Nevertheless, considering the correct use of ergogenic substances, athletic performance can be increased due to reasons such as increasing sporting conditioning, providing a faster recovery following an exercise, and allowing the body to adapt more easily and rapidly to training (Argan \& Hüseyin, 2009; Ünal, 2005). Ergogenic aids such as antioxidants (Braakhuis \& Hopkins, 2015), creatine (Kreider, 2003), caffeine (Bazzucchi et al., 2011; Hogervorst et al., 2008), L-carnitin (Karakus, 2014; Pandareesh \& Anand, 2013), BCAAs (losin, isolosin, valine) (Shimomura et al., 2004), some amino acids such as glutamine, arginine or etc., (Bowtell et al., 1999; Campbell et al., 2004), protein and carbohydrate supplements (McArdle et al., 2012), beta alanines (Hobson et al., 2012) have been proven by many studies to increase sports performance. For these reasons, it is thought that athletes may add them to their dietary list to benefit from them during the training or competition period (Argan \& Hüseyin, 2009; Leutholtz \& Kreider, 2001; Maughan, 1999; McArdle et al., 2012). Therefore, the purpose of this study is to investigate the nutritional ergogenic aids attitudes of the active Turkish kickboxers in terms of different variables such as gender, competition weight, competition category (age groups), education status, income levels, the status of the whether international athletes or not.

\section{Materials and Methods:}

This research is designed as a Scanning and Description Model. Scanning models are research models that aim to define a situation that is ongoing today or has existed in the past. The main goal in these models can be expressed as describing the existing situation as it is (Karasar, 2005).

A total of 459 trained athletes, 157 women and 302 men, who have actively participated in kickboxing competition at the national level of (Turkey) and international were selected. Official permission was obtained from the Turkey Kickboxing Federation prior to the study. Besides, the all study protocol was confirmed by the Ethics Committee of Erzurum Atatürk University, Institute of Winter Sports and Sport Sciences.

The information collection form prepared by the researcher, there are questions to determine the status of the participants such as gender, competition weight, competition category, university education level, and incomelevel.

The ATNSS, which consists of the sub-dimensions Benefit, Side Effects and Ethics, Natural Nutrition, was used for determining the athletes' ATNSS developed in 2009 by Argan and Köse (Argan \& Hüseyin, 2009). ATNSS is a 5-point Likert-type, 13-item, self-report-style measurement tool.

The scales completed by the athletes were checked in detail. Incomplete or incorrectly filled questionnaires were not evaluated. For data analysis, SPSS 22.00 package program was used and the skewness-kurtosis values were calculated. Considering the kurtosis and skewness values of ATNSS' sub-dimensions, it was observed that values have a normal distribution since the values were within the limits determined by Büyüköztürk (2012), Tabachnick \& Fidell (2015). Parametric tests were used in statistical analysis.

\section{Results:}

Results are summarized in Table-1 to 7 .

Frequency distributions are given for categorical variables in the analysis of the data. In addition, to check whether it has a given normal distribution, mode, median, arithmetic mean values and skewness and kurtosis coefficients were considered. Examining thekurtosis and skewness values of ATNSS' sub-dimensions, it was seen that 


\section{ORIGINAL ARTICLE}

the values were within the limits determined by Büyüköztürk (2012) and Tabachnick \& Fidell (2015) (-1 to + 1; $-1.5)$. $+1.5 ;-2.0$ to +2.0 ). It was observed that values have a normal distribution(Büyüköztürk, 2012; Tabachnick \& Fidell, 2015).

Table-1: Normality distribution of the participants' ATNSS' subdimensions

\begin{tabular}{llll}
\hline & Benefit & Side Effect \& Ethic & Natural Nutrition \\
\hline $\mathrm{N}$ & 459 & 459 & 459 \\
Mean & 3.14 & 2.31 & 2.52 \\
Median & 3.40 & 2.25 & 2.50 \\
Std. Deviation & 1.21 & 0.85 & 0.98 \\
Skewness & -.362 & .584 & .285 \\
Kurtosis & -1.00 & 0.123 & -.810 \\
\hline
\end{tabular}

Table-2: Characteristics of the athletes participating in this study (PESHS: Physical education sport high school)

\begin{tabular}{llll}
\hline Variables & Category & $\mathrm{N}$ & $\%$ \\
\hline Gender & Male & 302 & 65.8 \\
& Female & 157 & 34.2 \\
Age groups/Category & Cadets (13-15 years) & 64 & 13.9 \\
& Juniors (16-18 years) & 141 & 30.7 \\
& Seniors (+19 years) & 254 & $55 \cdot 3$ \\
Competition Weight & 50 kg and below & 57 & 12.4 \\
& 51-6o kg & 106 & 23.1 \\
& 61-70 kg & 133 & 29 \\
& 71-80 kg & 85 & 18.5 \\
& 81-9o kg & 42 & 9.2 \\
Family Income Status & 91 kg and above & 36 & 7.8 \\
& Below 30oo TL & 185 & 40.3 \\
& Between 30o1-70oo TL & 231 & 50.3 \\
Education Status & Above 70o1 TL & 43 & 9.4 \\
of the University & Sport Sci. Faculty/PESHS & 105 & 22.9 \\
& Others & 134 & 29.2 \\
International/National & Didn't studied university & 220 & 47.9 \\
Athletes Status & International & 127 & 27.7 \\
If international athlete, & National & 332 & 72.3 \\
have an success? & International success & 65 & 51.2 \\
& No international success & 62 & 48.8 \\
\hline
\end{tabular}

The total of 459 kickboxers participated in the study. 302 of them male and 157 of them were female of these kickboxers. 127 of these athletes were international athletes, while 332 were national athletes. Detailed demographic characteristics of the athletes are presented in table-2.

Table-3: Independent $t$ test results of the ATNSS' subdimensions of the kickboxers, according to the gender variable ATNSS: Attitudes Toward Nutritional Sports Supplements

\begin{tabular}{llllll}
\hline Parameter & Gender & $\mathrm{X}$ & $\mathrm{SD}$ & $\mathrm{t}$ & $\mathrm{p}$ \\
\hline Benefit & Male & 3.10 & $\mathbf{1 . 3 0}$ & -0.881 & 0.379 \\
& Female & $\mathbf{3 . 2 0}$ & $\mathbf{1 . 0 2}$ & & \\
Side Effect \& Ethic & Male & $\mathbf{2 . 1 8}$ & $\mathbf{0 . 8 5}$ & -4.558 & $<0.001$ \\
& Female & $\mathbf{2 . 5 6}$ & $\mathbf{0 . 8 1}$ & & \\
Natural Nutrition & Male & $\mathbf{2 . 4 0}$ & $\mathbf{0 . 9 7}$ & -3.907 & $<0.001$
\end{tabular}

Ambient Science, 2020: Vol. 07(Sp1); 33-38 DOI:10.21276/ambi.2020.07.sp1.oa04

Female $\quad 2.77 \quad 0.95$

The scores of women were statistically higher than male kickboxers in the Side Effects and Ethics ( $\mathrm{p}<\mathrm{o.oo1}$ ) and Natural Nutrition ( $\mathrm{p}<\mathrm{o.0o1}$ ) sub-dimensions, while no statistically significant difference was seen in the Benefit sub-dimension ( $>>0.05)$ as a result of the t-test analysis between the gender and ATNSS' sub-dimensions.

Table-4: ANOVA results of the ATNSS' sub-dimension levels of the kickboxers participating in the study according to the competition category variable

\begin{tabular}{|c|c|c|c|c|c|c|}
\hline & $\begin{array}{l}\text { Competition } \\
\text { Category }\end{array}$ & $\mathrm{X}$ & SS & $\mathrm{F}$ & $\mathrm{p}$ & \\
\hline \multirow[t]{3}{*}{ Benefit } & Cadets (c) & 2.68 & 1.17 & \multirow[t]{3}{*}{5.994} & \multirow[t]{3}{*}{$0.003^{*}$} & $g>y$ \\
\hline & Juniors (j) & 3.13 & 1.19 & & & $\mathrm{~b}>\mathrm{y}$ \\
\hline & Seniors (s) & 3.26 & 1.21 & & & \\
\hline Side Effect \& & Cadets (c) & 2.27 & 0.80 & \multirow[t]{3}{*}{0.114} & \multirow[t]{3}{*}{0.892} & - \\
\hline \multirow[t]{2}{*}{ Ethic } & Juniors (j) & 2.33 & 0.88 & & & \\
\hline & Seniors (s) & 2.31 & 0.85 & & & \\
\hline \multirow{3}{*}{$\begin{array}{l}\text { Natural } \\
\text { Nutrition }\end{array}$} & Cadets (c) & 2.58 & 1.01 & \multirow[t]{3}{*}{3.862} & \multirow[t]{3}{*}{$0.022^{*}$} & \multirow[t]{3}{*}{$g>b$} \\
\hline & Juniors (j) & 2.70 & 1.03 & & & \\
\hline & Seniors (s) & 2.42 & 0.93 & & & \\
\hline
\end{tabular}

According to the ANOVA analysis between the competition categoryand ATNSS' sub-dimensions of the kickboxers, there was a significant difference in the Benefit and Natural Nutrition sub-dimensions while there was no significant difference in the Side Effect and Ethics subdimensions ( $p>0.05)$.Tukey Post-hoc indicated that the scores of kickboxers in cadet category were significantly lower thankickboxers in junior category $(\mathrm{p}=0.038)$, and than the senior category $(\mathrm{p}=\mathrm{o.002})$ in the Benefit subdimension. In the Natural Nutrition sub-dimension, the scores of the kickboxers in the junior category were significantly higher than the kickboxers in the senior category $(\mathrm{p}=0.018)$.

Table-5: ANOVA results of the ATNSS' sub-dimension

levels of the kickboxers participating in the study according to the family's income status variable

\begin{tabular}{|c|c|c|c|c|c|c|}
\hline & $\begin{array}{l}\text { Family Income } \\
\text { Status }\end{array}$ & X & SS & $\mathrm{F}$ & $\mathrm{P}$ & Fark \\
\hline Benefit & $\begin{array}{l}<3000 \text { TL (a) } \\
\text { > 3001-70oo TL (b) } \\
>\text { Above 7001 TL (c) }\end{array}$ & $\begin{array}{l}3.06 \\
3.17 \\
3.34\end{array}$ & $\begin{array}{l}1.29 \\
1.17 \\
1.04\end{array}$ & 1.091 & 0.337 & - \\
\hline $\begin{array}{l}\text { Side Effect \& } \\
\text { Ethic }\end{array}$ & $\begin{array}{l}<3000 \mathrm{TL}(\mathrm{a}) \\
\sim 3001-7000 \mathrm{TL}(\mathrm{b}) \\
>7001 \mathrm{TL}(\mathrm{c})\end{array}$ & $\begin{array}{l}2.16 \\
2.39 \\
2.52\end{array}$ & $\begin{array}{l}0.84 \\
0.87 \\
0.71\end{array}$ & 5.469 & 0.004 & $\begin{array}{l}\mathrm{b}>\mathrm{a} \\
\mathrm{c}>\mathrm{a}\end{array}$ \\
\hline $\begin{array}{l}\text { Natural } \\
\text { Nutrition }\end{array}$ & $\begin{array}{l}<3000 \mathrm{TL}(\mathrm{a}) \\
\sim 3001-7000 \mathrm{TL}(\mathrm{b}) \\
>7001 \mathrm{TL}(\mathrm{c})\end{array}$ & $\begin{array}{l}3.38 \\
2.57 \\
2.92\end{array}$ & $\begin{array}{l}0.96 \\
0.98 \\
0.90\end{array}$ & 5.812 & $0.003^{*}$ & $a>c$ \\
\hline
\end{tabular}

Examining the results of ANOVA analysis between the family's income status and ATNSS' sub-dimensions of the participants, significant difference was observed in the Side Effect and Ethics and Natural Nutrition sub-dimensions while there was no significant difference in the Benefit sub-dimension. Side Effect and Ethic sub-dimension scores of the athletes with family income 
level of 3000 TL or below are statistically lower compared to athletes with family income between 3001-7000 TL $(\mathrm{p}=0.014)$ and athletes with family income level $7001 \mathrm{TL}$ and above $(\mathrm{p}=0.030)$ according to the post-hoc analysis.In the natural nutrition subdimension, the scores of the athletes whose family income level was 3000 TL or below were significantly higher than the athletes whosefamily income level was 7001 TL or above $(\mathrm{p}=0.003)$.

Table-6: Independent group t test results of the ATNSS' sub-dimensions of the kickboxers as per the education status of university variable

\begin{tabular}{|c|c|c|c|c|c|}
\hline & $\begin{array}{l}\text { Education status } \\
\text { in university }\end{array}$ & $\mathrm{X}$ & SS & $\mathrm{F}$ & $\mathrm{p}$ \\
\hline Benefit & $\begin{array}{l}\text { Sprort Sci. Fac./ PESHS } \\
\text { Others }\end{array}$ & $\begin{array}{l}3.32 \\
2.89\end{array}$ & $\begin{array}{l}1.26 \\
1.19\end{array}$ & 2.692 & 0.008 \\
\hline Side Effect \& & Sport Sci. Fac./ PESHS & 2.24 & 0.78 & -1.099 & 0.273 \\
\hline Ethic & Others & 2.36 & 0.90 & & \\
\hline Natural & Sport Sci. Fac./ PESHS & 2.46 & 0.89 & -0.43 & 0.966 \\
\hline Nutrition & Others & 2.47 & 0.99 & & \\
\hline
\end{tabular}

As a result of the t-test analysis between the education status of university and ATNSS' sub-dimensions of the participants, it was determined that the kickboxers studying at the Faculty of Sports Sciences / PESHS had statistically higher benefit sub-dimension scores than the kickboxers studying in other departments $(p=0.008)$. However, no significant difference was observed between the Side Effects and Ethics and Natural Nutrition subdimensions according to the kickboxers' education status of university.

Table-7: Independent group t test results of the ATNSS' sub-dimensions of the kickboxers as per the education status of university variable

\begin{tabular}{llllll}
\hline & $\begin{array}{l}\text { Internat./National } \\
\text { Athletes Status }\end{array}$ & X & SS & F & P \\
& Internat. Athlete & 3.37 & 1.23 & 2.590 & 0.010 \\
Benefit & National Athlete & 3.05 & 1.19 & & \\
Side Effect \& & Internat. Athlete & 2.18 & 0.78 & $\mathbf{- 2 . 0 4 2}$ & 0.042 \\
Ethic & National Athlete & 2.36 & 0.87 & & \\
Natural & Internat. Athlete & 2.37 & 0.90 & $\mathbf{- 2 . 0 2 5}$ & $\mathbf{0 . 0 4 3}$ \\
Nutrition & National Athlete & 2.58 & 1.00 & &
\end{tabular}

Moreover, considering the analysis between the status of international or national athlete and ATNSS' sub-dimensions of the kickboxers, it is one of the prominent results that the scores of international athletes were significantly higher than national athletes in the Benefit sub-dimension ( $\mathrm{p}=\mathrm{o} .010)$. However, the scores of international athletes weresignificantly lower than national athletes in the subdimensions of Side effects and Ethics $(\mathrm{p}=\mathrm{0.042})$ and Natural Nutrition $(\mathrm{p}=0.043)$. No significant difference was observed in the ATNSS' subdimensions for the variables of competition weight and whether they have an international success or not ( $\mathrm{p}>0.05)$

\section{Discussion and Conclusion:}

Athletic performance, mental and physical effects of sports for all ages are among the subjects that are up-to-date (Bardakci et al., 2019; Çelik \& Sahin, 2013; Kirkbir, 2017). However, increasing athletic performance with nutritional methods and ergogenic supplements is alsocrucial for professional athletes (Argan \& Hüseyin, 20o9; Maughan,
1999). For this purpose,the use of nutritional sports supplements is becoming widespread and many ergogenic support products are marketed to affect health and performance (Young \& Stephens, 2009).Therefore, we aimed to determine the active kickboxing athletes' attitudes towards nutritional ergogenic in Turkeyin the present study. There are limited studies in which we can discuss the results of this study since this is the first study on combat sports in this issue.

The following results were obtained from the study conducted on a total of 459 active kickboxers, including 127 international kickboxers in Turkey. The scores of women were statistically higher than male kickboxers in the Side Effects and Ethics and Natural Nutritionsub-dimensions, but no statistically significant difference was found in the Benefit sub-dimension between the male and female kickboxers. In a study conducted by Öztürk (2017), he did not report any statistically difference between male and female participants on nutritional attitudes.In the present study, there was a difference between men and women in the two sub-dimensions (Side Effects and Ethics and Natural Nutrition). The difference between the studies may stem from to the difference in the participant population and the content of the research method.

As a result of the analysis between the competition category and ATNSS' sub-dimensions of the kickboxers, it isdiscovered that there was a significant difference in the Benefit and Natural Nutrition sub-dimensions while no significant difference was found in the Side Effect and Ethics sub-dimension. It was determined that the scores of kickboxers in cadet category were significantly lower than kickboxers in junior category and the senior category in the Benefit sub-dimension. In the Natural Nutrition subdimension, the scores of the kickboxers in the junior category were significantly higher than the kickboxers in the senior category. The increasing knowledge and interest in ergogenic supplements and their benefits with age may be the reason why cadet kickboxers' scores in the Benefit sub-dimension are lower than older (juniors and seniors) ones (Argan \& Hüseyin, 2009).

According to the analysis between family's income status and ATNSS' sub-dimensions of the participants, Side Effect and Ethic sub-dimension scores of the athletes with family income level of 3000 TL or below are statistically lower compared to athletes with family income between 3001-7000 TL and athletes with family income level $7001 \mathrm{TL}$ or above. In the natural nutrition sub-dimension, the scores of the athletes whose family income level was $3000 \mathrm{TL}$ or below were significantly higher than the athletes whose family income level was 7001 TL or above. No significant difference was found in the Benefit sub-dimension. It is thought that this kind of difference may stem from the purchase of ergogenic products with money (Herma et al., 2006), and this situation may affect the views of athletes on 


\section{ORIGINAL ARTICLE}

these issues in relation to their economic conditions

Considering the analysis between the education status of university and ATNSS' sub-dimensions of the participants, it is seen that the kickboxers studying at the Faculty of Sports Sciences / PESHS had statistically higher benefit sub-dimension scores than the kickboxers have not studied in these departments. The higher level of knowledge about ergogenic aids, sports nutrition and physiology may cause this difference since the students of the faculty of sports sciences have been studied in exercise physiology and exercise nutrition courses in the curriculum according to Turkish Higher Education Institutes (Açikada \& Ergen, 1991; YÖK, 2020). In addition, the positive effect of the courses studied on the use of nutritional supplements Parr et al. (1984), which supports our study results.

Examining the results of the analysis between ATNSS' sub-dimensions and the status of whether they are international or national athlete of the kickboxers, the scores of international athletes were seen significantly higher than national athletes in the Benefit sub-dimension. However, the scores of international athletes were significantly lower than national athletes in the subdimensions of Side effects and Ethics and Natural Nutrition. It may have led athletes to be more knowledgeable about the positive effects of ergogenic aids, as international athletes compete more in major tournaments.

Conclusively, the correct use of some ergogenic substances, athletic performance can be increased for reasons such as increasing sportive fitness, faster recovery after exercise, and easier adaptation of the body to training. Hence, based on the present study results as well, it is thought that informing the kickboxers about nutritional ergogenic supports in detail may be important in terms of increasing awareness and sporting performance.

\section{References:}

Açikada, C. \& Ergen, E. (1991): Hacettepe Üniversitesi Egitim Fakültesi Spor Bilimleri Ve Teknolojisi Bölümü Müfredat Programinin Incelenmesi. Spor Bilimleri Dergisi, 3(4):31-39.

Argan, M. \& Hüseyin, K. (2009): Sporcu Besin Desteklerine (Sports Supplements) Yönelik Tutum Faktörleri: Fitness Merkezi Katilimcilari Üzerine Bir Arastirma. Spor Bilimleri Dergisi, 20(4):152-164.

Bahrke, M. S., Yesalis, C. E., Kopstein, A.N. \& Stephens, J.A. (200o): Risk factors associated with anabolic-androgenic steroid use among adolescents. Sports Med., 29(6), 397-405.

Bardakci, S., Caz, C. \& Kayhan, R. F. (2019): Investigating the effects of Athletic identity on athlete burnout. Med. dello Sport, 72(4):552-561.

Bazzucchi, I., Felici, F., Montini, M., Figura, F. \& Sacchetti, M. (2011): Caffeine improves neuromuscular function during maximal dynamic exercise. Muscle Nerve, 43(6):839-844.

Bowtell, J.L., Gelly, K., Jackman, M., Patel, A., Simeoni, M. \& Rennie, M. (1999): Effect of oral glutamine on whole body
Ambient Science, 2020: Vol. 07(Sp1); 33-38 DOI:10.21276/ambi.2020.07.sp1.oa04

carbohydrate storage during recovery from exhaustive exercise. J.App. Physiol., 86(6): 1770-1777.

Braakhuis, A.J. \& Hopkins, W.G. (2015): Impact of dietary antioxidants on sport performance: a review. Sports Med., 45(7):939-955.

Büyüköztürk, S. (2012): Veri Analizi El Kitabi.(17. Basim). Pub. by: Ankara: PegemAAkademi Yayinlari.

Campbell, B.I., La Bounty, P.M. \& Roberts, M. (2004): The ergogenic potential of arginine. J. Int. Soc. Sports Nutr., 1(2):1-4.

Çelik, A. \& Sahin, M. (2013): Spor ve çocuk gelisimi. Int. J. Soc. Sci., $6(1), 467-478$.

Ersoy, G. (2010): Egzersiz ve Spor Performansi Için Beslenme. Pub. by: Betik Kitap Yayin Dagitim, Ankara.

Gartland, S., Malik, M. \& Lovell, M. (2001): Injury and injury rates in Muay Thai kick boxing. Br. J. Sports Med., 35(5), 308-313.

Hargreaves, M., Hawley, J.A. \& Jeukendrup, A. (2004): Pre-exercise carbohydrate and fat ingestion: effects on metabolism and performance. J. Sports Sci., 22(1):31-38.

Heaney, S., O'Connor, H., Gifford, J. \& Naughton, G. (2010): Comparison of strategies for assessing nutritional adequacy in elite female athletes' dietary intake. Int. J. Sport Nutr. Exerc. Metabol., 20(3):245-256.

Heil, D.P. (2010): Acid-base balance and hydration status following consumption of mineral-based alkaline bottled water. J. Int. Soc. Sports Nutr., 7(1):29.

Herman, D.R., Harrison, G.G. \& Jenks, E. (2006): Choices made by low-income women provided with an economic supplement for fresh fruit and vegetable purchase. $\lfloor$. Am. Diet. Asso., 106(5),:740-744.

Himes, J.H. (1991): Anthropometric Assessment of Nutritional Status. Pub. by: Wiley-Liss.

Hobson, R.M., Saunders, B., Ball, G., Harris, R. \& Sale, C. (2012): Effects of $ß$-alanine supplementation on exercise performance: a meta-analysis. Amino acids, 43(1):25-37.

Hogervorst, E., Bandelow, S., Schmitt, J., Jentjens, R., Oliveira, M., Allgrove, J. et al. (2008): Caffeine improves physical and cognitive performance during exhaustive exercise. $\underline{\text { Med. Sci. }}$ Sports Exerc., 40(10):1841-1851.

Holway, F.E. \& Spriet, L.L. (2011). Sport-specific nutrition: practical strategies for team sports. L. Sports $S_{c i}$., 29(S1):S115S125.

Jentjens, R. \& Jeukendrup, A. (2003): Effects of pre-exercise ingestion of trehalose, galactose and glucose on subsequent metabolism and cycling performance. Eu. J. Appl. Physiol., 88(4-5):459-465.

Juhn, M.S. (2003): Popular sports supplements and ergogenic aids. Sports Med., 33(12):921-939.

Karakus, M. (2014): Sporcularda ergojenik destek. Spor Hekimligi Dergisi, 49(4): 155-167.

Karasar, N. (2005): Bilimsel arastirma yöntemi (17. Baski), pp. 81-83. Pub. by: Nobel yayin dagitim, Ankara.

Kirkbir, F. (2017): Investigating the effect of mental imagery on the success of athlete students at Trabzon University, Turkey. $\underline{E u}$. L. Phy. Edu. Sport Sci., 3(11):286-292.

Kreider, R.B. (2003): Effects of creatine supplementation on 
performance and training adaptations. Mol. Cell. Biochem., 244(1-2):89-94.

Kutscher, E.C., Lund, B.C. \& Perry, P. J. (2002): Anabolic steroids. Sports Med., 32(5):285-296.

Leutholtz, B., \& Kreider, R. (2001): Exercise and sport nutrition. Nutri. Health, 207-239.

Maughan, R. (1999): Nutritional ergogenic aids and exercise performance. Nutr. Res. Rev., 12(2):255-28o.

McArdle, W.D., Katch, F.I. \& Katch, V.L. (2012): Sports and Exercise Nutrition (4 ed.): LWW; Fourth, North American edition (May30, 2012).

Ormsbee, M.J., Bach, C.W. \& Baur, D.A. (2014): Pre-exercise nutrition: the role of macronutrients, modified starches and supplements on metabolism and endurance performance. Nutrients, 6(5): 1782-18o8.

Ozan, M., Buzdagli, Y., Siktar, E. \& Ucan, I. (2020): The Effect of Protein and Carbohydrate Consumption during 10-Week Strength Training on Maximal Strength and Body Composition.Int.J. Appl. Exerc. Physiol., 9(6):149-159.

Özbay, S. \& Ulupnar, S. (2020): Strength-Power Tests are More Effective When Performed After Exhaustive Exercise in Discrimination Between Top-Elite and Elite Wrestlers. L. Strength Condition. Res.

Pandareesh, M. \& Anand, T. (2013): Ergogenic effect of dietary Lcarnitine and fat supplementation against exercise induced physical fatigue in Wistar rats. J. Physiol. Biochem., 69(4):799-809.

Parr, R., Porter, M. \& Hodgson, S. (1984): Nutrition knowledge and practice of coaches, trainers, and athletes. Phys. Sportsmed., 12(3):126-138.

Rico-Sanz, J. (1998): Body Composition and Nutritional. Int. J. Sport Nutr., 8:11-123.

Rodriguez, N., Di Marco, N. \& Langley, S. (2009): American Dietetic Association Dietitians of Canada, American College of Sports Medicine. American College of Sports Medicine position stand. Nutrition and athletic performance. Med Sci Sports Exerc., 41(3):709-731.

Rudman, D., Feller, A.G., Nagraj, H.S., Gergans, G.A., Lalitha, P. Y., Goldberg, A.F. et al., (1990): Effects of human growth hormone in men over 60 years old. New Eng. J. Med., 323(1):16.

Shahidi, N. T. (2001): A review of the chemistry, biological action, and clinical applications of anabolic-androgenic steroids. Clin. Therap., 23(9): 1355-1390.

Shimomura, Y., Murakami, T., Nakai, N., Nagasaki, M. \& Harris, R. A. (2004): Exercise promotes BCAA catabolism: effects of BCAA supplementation on skeletal muscle during exercise. I. Nutri., 134(6),:583S-1587S.
Singbartl, G. (1994): Adverse events of erythropoietin in longterm and in acute/short-term treatment. Clin. Investig., 72(6 Suppl):S36-S43.

Slimani, M., Chaabene, H., Miarka, B., \& Chamari, K. (2017): The activity profile of elite low-kick kickboxing competition. Int. L. Sports Physiol. Perform., 12(2):182-189.

Sonksen, P. (2001): Hormones and Sport-Insulin, growth hormone and sport. J. Endocrinol., 170(1):13-26.

Stand, P. (1996): Exercise and fluid replacement. Med. Sci. Sports Exerc., 28.

Sunder-Plassmann, G., \& Hörl, W.H. (2001): Effect of erythropoietin on cardiovascular diseases. Am. J. Kidney Dis., 38(4): $\mathrm{S}_{20} \mathrm{O} 25$.

Sundgot-Borgen, J., Berglund, B., \& Torstveit, M.K. (2003): Nutritional supplements in Norwegian elite athletes-impact of international ranking and advisors. Scandinavian J. Med. Sci. Sports, 13(2):138-144.

Tabachnick, B., \& Fidell, L. (2015): Çok degiskenli istatistiklerin kullanimi (M. Baloglu, Çev.). Pub. by: Nobel, Ankara.

Tarnopolsky, M.A., MacDougall, J.D. \& Atkinson, S.A. (1988): Influence of protein intake and training status on nitrogen balance and lean body mass. J.Appl. Physiol., 64(1):187-193.

Tawfik, S., El Koofy, N. \& Moawad, E.M.I. (2016): Patterns of Nutrition and Dietary Supplements Use in Young Egyptian Athletes: A Community-Based Cross-Sectional Survey. $\underline{\text { Plos }}$ One, $11(8)$, e0161252.

Ünal, M. (2005): Sporcularda kreatin destegi ve egzersiz performansi üzerine etkileri.Genel Tip Dergisi, 15(1):43-49.

Young, C.R. \& Stephens, M.B. (2009). Sports and nutritional supplement use in USMC recruits: a pilot study. Military Med., 174(2):158-161.

YÖK. (2020): Yüksek Ögretim Kurumlari/Higher Education Institutions, Physical education and sports undergraduate program. Online Note

Zazryn, T.R., Finch, C.F. \& McCrory, P. (2003): A 16 year study of injuries to professional boxers in the state of Victoria, Australia. Br.J. Sports Med., 37(4):321-324.

Zorba, E. (1999): Herkes için sporve fiziksel uygunluk (Sports for all and physical fitness). Pub. by: GSGM Egitim Dairesi Yayinlari, Ankara, Turkey. 